\title{
Philip Corboy and the Construction of the Plaintiffs' Personal Injury Bar
}

\section{Sara Parikh and Bryant Garth}

\begin{abstract}
Drawing on the career of Philip Corboy, this article examines the construction of the plaintiffs' personal injury bar in the second half of the 20 th century. Through a relational biography based on Mr. Corboy's career, we look at the development of this subprofession in the context of the sociopolitical environment within which Mr. Corboy and his peers operated, the social capital they possessed, and the particular strategies they used as they worked to establish both a professional and market niche. This analysis shows how and why $\mathrm{Mr}$. Corboy and his peers constructed a thriving subprofession that is characterized by a unique blend of working-class ideology, trial craft, professional bar leadership, Democratic politics, local philanthropy, and a market referral system - all of which reinforce the dominance and prestige of its own elite.
\end{abstract}

Sara Parikh is a Postdoctoral Fellow at the American Bar Foundation. Her doctoral dissertation explored the Chicago plaintiffs' personal injury bar. Drawing upon social network theory and analysis, she examined the hierarchy in the profession, the structure of its market, and the juxtaposition of professional cohesion and market competition. She is currently working on a book based on her dissertation. Sara is also Vice President of Leo J. Shapiro and Associates, a behavior and opinion research firm, where she specializes in litigation research.

Bryant Garth is a senior research fellow of the American Bar Foundation. His recent research has concentrated on the globalization of law and legal institutions, focusing currently on Asia. Recent books include The Internationalization of the Palace Wars: Lawyers, Economists, and the Contest to Transform Latin American States (with Yves Dezalay) (Chicago: University of Chicago Press, 2002), and two edited volumes: Global Prescriptions: The Construction, Exportation, and Importation of a New Legal Orthodoxy (with Yves Dezalay) (Ann Arbor: University of Michigan Press, 2002) and Looking Back at Law's Century (with R. Kagan and A. Sarat) (Ithaca, N.Y.: Cornell University Press, 2002).

The authors would like to thank Philip Corboy for making himself freely available to us during the course of this project. We are also grateful to Jack Heinz for his especially helpful comments on an earlier draft of this article. 
Philip Corboy personifies the elite of the plaintiffs' personal injury bar in Chicago. He is an Irish Catholic Democrat from a working-class family; he attended a local law school; and he gradually built both his own career and a prosperous firm that is consistently one of the leaders in personal injury practice in Chicago. He is renowned as a courtroom advocate, and he speaks out more generally on the need for lawyers to take on large corporations on behalf of ordinary people victimized by corporate wrongdoing. He provides the model and often the personal connection and mentorship for successful personal injury lawyers who have followed him.

Corboy's story is also emblematic for other reasons. After his service during World War II and with funds made available from the GI Bill, he graduated at the top of his law school class. Despite this academic achievement, he lacked access to the careers found at the prestigious corporate law firms. Instead, he followed another path, taking advantage of opportunities that were available to individuals with his background and credentials. This article examines how Corboy established himself at the center of what was then emerging as a recognized personal injury bar. Yet this is not just a story about Philip Corboy. The trajectory of Corboy's career parallels the advancement of the personal injury bar, and Corboy himself helped to build and shape this subprofession. We therefore draw upon Corboy's background and career to illuminate the development of the plaintiffs' bar in the second half of the 20th century.

Philip Corboy, who is now 80 years old, has been at the top of the personal injury bar in Chicago for most of the period after World War II. He was among the first personal injury lawyers in the nation to secure a $\$ 1$ million jury verdict (1974). He has secured over 250 settlements or jury awards of $\$ 1$ million or more, including a $\$ 25$ million settlement on behalf of a woman whose husband was killed in the 1989 United Airlines crash in Sioux City, Iowa. He has gained professional distinction as president of the Chicago Bar Association (1972-73) and the Illinois Trial Lawyers Association (1963-64), and as chair of the American Bar Association Section of Litigation (1979-80). He has the recognition of his peers, who know him as the "dean" of the personal injury bar in Chicago. Corboy's enduring prominence in Chicago is also evident in studies of the Chicago bar. In the 1975 and 1995 American Bar Foundation studies of the Chicago bar, Corboy was the most connected of all local "notables" (Heinz and Laumann 1982; Heinz, Nelson, et al. forthcoming). He also has long-standing connections to the Democratic Party in Chicago and elsewhere, and a long list of philanthropic activities. Corboy even has a street named after him, Philip $\mathrm{H}$. Corboy Way, which appropriately runs for one block in front of the Cook County Circuit Court headquarters (Richard J. Daley Center) in downtown Chicago.

More generally, Corboy personifies the characteristics of elite personal injury lawyers in Chicago today. The elite tend to be Catholic or Jewish males who come from modest backgrounds and attend local law schools. They are at the top of a referral chain that channels the biggest cases to them and their 
firms, and they reinforce their position through their ability and willingness to bring high-risk cases to juries. In their professional lives they demonstrate their commitment to the collective through professional leadership, political activism, local philanthropy, and mentoring young lawyers like themselves who follow in their footsteps. ${ }^{1}$ In this article we examine how these came to be the defining traits of elite plaintiffs' lawyers in Chicago.

At the same time, Corboy's story provides a mean to explore the sociological development of this major "subprofession"-the plaintiffs' bar. Their courtroom successes, professional and political activities, and local philanthropy all reinforce the stature of the elite within the plaintiffs' bar. This has translated into a substantial upgrading in the general social status of this segment of the personal injury bar. The personal injury bar now produces many bar leaders, and legal scholars have in recent years produced a much more favorable view than was found a generation ago (Daniels and Martin 1999, 2000; Kritzer 1997, forthcoming; Kritzer and Krishnan 1999; Parikh 2001).

Yet one of the challenges of a study of a relatively well-established subprofession is that its characteristics now seem natural and inevitable. Corboy's career provides a means to explain why this subprofession has particular characteristics, why they tend to endure, and how they serve a professional hierarchy that places Corboy and others like him at the top. We cannot provide an account of possible alternative histories, since the losers have left few traces, but we can put the current situation in perspective by seeing how a subprofession emerged that defines itself as the culmination of a struggle for justice on behalf of ordinary people against powerful corporations (Jacobson and White 2004). The emergence of this subprofession was not inevitable, nor was it inevitable that this particular group of lawyers, and not others from the legal profession or elsewhere, came to define an area of practice focused on one side of personal injuries. A sociological account also shows what holds this subprofession together and what might threaten its survival in the future--beyond the obvious candidates like tort reform.

\section{OUR APPROACH}

This article is based on archival data, lengthy interviews that we have undertaken with Corboy and other personal injury lawyers in Chicago, and

1. The high-end and elite lawyers epitomized by Corboy represent only a small minority of Chicago plaintiffs' lawyers. As others have found, the personal injury bar is a highly stratified subprofession (Carlin 1962; Daniels and Martin 1999; Kritzer 2001; Van Hoy 1999). The majority of Chicago plaintiffs' lawyers handle a high volume of smaller cases - mostly automobile accidents and other minor injury cases valued in the $\$ 10,000-\$ 30,000$ range (Parikh 2001). These "low-end" practitioners are also predominantly Catholic or Jewish males from working-class backgrounds and local law schools. These low-end lawyers are less active in the profession, yet they are integrated into a community of personal injury lawyers that is defined and defended by its most elite practitioners. 
on 62 in-depth interviews with Chicago plaintiffs' lawyers that Parikh conducted for her study of social networks in the plaintiffs' personal injury bar. ${ }^{2}$

Our examination of the development and maturation of this subprofession is consistent with a well-developed body of sociological research in the law-and-society tradition. Richard Abel's work on the legal profession in the United States and England, in particular, focuses on the way lawyers seek to gain status for their profession at the same time that they seek to build and protect the markets for their services (e.g., Abel 1989, 2003; Abel and Lewis 1995). Drawing on Larson's (1977) concept of the twin aims (market and status) of the "professionalism project," Abel emphasizes lawyers' efforts to limit entry into the profession, enhance professional credentials, expand markets, and control competition from inside and outside the profession. Abel's theoretical approach also encompasses lawyers' efforts to maintain and enforce professional values such as pro bono and public service. Abel consistently shows the necessity to situate legal professionalism-including legal aid, educational reforms, and even legal ethics-in relation to the essentials of building a market and a professional status that can reap market rewards.

The markets and status model of professionalism provides the basic orientation, but in our opinion it shares some of the limitations of the rational-actor model of neoclassical economics. In the neoclassical model, actors in a market strategically select from a range of options as they seek to maximize profit through one-shot transactions with anonymous exchange partners. Little, if any, weight is placed on the environment within which these actors operate. Economic sociologists, in contrast, view markets as socially structured and embedded in a larger sociopolitical context that shapes actors' choices. Just as the behavior of markets and market actors cannot be explained solely from the perspective of economic rationality, the behavior of professional markets and professionals cannot be explained solely through what could be termed "professional rationality."

The sociological quest to move beyond economic rationality has gained considerable momentum in the past two decades. Much of the literature goes

2. In addition to interviews we conducted jointly with Corboy and other Chicago personal injury lawyers, this article draws heavily upon research conducted by Sara Parikh for her doctoral dissertation (2001). Parikh's research uses social network analysis to examine the hierarchy in the profession, the cohesion of its members, the structure of the market for personal injury cases, and the juxtaposition of market competition and professional cohesion. Parikh's dissertation was based on 62 in-depth interviews conducted between 1998 and 2000 with a stratified sample of low-end, high-end, and elite members of the Chicago plaintiffs' personal injury bar. The majority of the interviews were conducted with attomeys identified from a random sample of case filings in the Cook County Circuir Court. In addition, interviews were conducted with 11 "elite" members of the Chicago plaintiffs' personal injury bar. Borrowing the method adopted in the studies of the Chicago bar by Heinz et al. (Heinz and Laumann 1982; Heinz, Nelson, et al. forthcoming), the elite were identified before interview. ing began through discussions with "informants" inside and outside of the personal injury bar. Overall, Parikh contacted 82 personal injury attorneys for her research and 62 ( 78 percent) agreed to participate. Eleven out of 12 elites agreed to participate. 
under the heading of "economic sociology" (Swedberg 2003; Fligstein 2001), but it is also found in the "new institutionalism," which is concerned with the socially constructed behavior of organizations and institutions and the need for the legitimation of particular models and approaches (see, e.g., Powell and DiMaggio 1991). The same approach is also evident in Pierre Bourdieu's concept of "habitus," developed in order to break with "the theory of homoeconomicus as rational agent" (Bourdieu and Wacquant 1992,120-21). All these scholars use the conceptual tool of the "field" as a means to uncover "all those practices that are reasonable without being the product of a reasoned purpose and, even less, of conscious computation" (120). Fligstein (2001), for example, calls for a "political-cultural" approach to the sociology of markets, highlighting the importance of examining market construction within a particular field.

The field - analogous to a playing field - is a basic tool for this kind of research. Intentionally left without precise boundaries, the field is defined as a semiautonomous social space with a specific hierarchy and power structure and a particular set of resources. In examining an emerging market, organization, or profession, scholars with this perspective tend to take a special interest in the sociopolitical context and in the relationships (i.e., social networks) among actors in the field. The power of actors in a field typically depends on links to outside sources of power. The sociopolitical context and social networks reveal the historical constraints and opportunities that led to the development and legitimation of a particular field. Our analysis, then, seeks to explain that what now seems natural and normal-and even economically and professionally rational--conceals hierarchies, connections to power, and other possibilities not apparent in traditional professional histories that focus mainly on the strategies used to build markets and status.

Our approach in this article can be characterized as "relational biography" (Dezalay and Garth 2002, 9). Relational biography relies on career histories to reveal the particular sociopolitical context that shapes actors' choices, the social networks that key actors are able to draw upon, and the strategies that they use as they attempt to make their way in the professional and social world in which they find themselves. By "strategy," therefore, we do not necessarily mean self-conscious efforts with rational ends such as to build markets and prestige, but rather "reasonable" choices made in the context of specific opportunities and constraints.

More precisely, our goal is to explain the development of the personal injury bar by examining the world that Corboy and his peers inhabited and how they perceived and acted upon the constraints and opportunities in that world. In Bourdieu's terms, we wish to examine how Corboy operated given the "capital" he could mobilize, including the social networks and personal characteristics that might seem unrelated to the specific tasks of building a successful law practice. 
We use a narrative approach to show how the choices Corboy and his peers made were shaped by their environment. In telling this story, we highlight a few features especially relevant to our theoretical framework, but the theoretical implications are largely saved until the end. ${ }^{3}$

Corboy entered the legal profession shortly after World War II and remains a leader in the Chicago plaintiffs' bar today. Therefore, this article covers the construction of the profession between World War II and the present. We understand that we could have started our story earlier. There were, after all, important developments and actors in the plaintiffs' bar prior to World War II that, no doubt, set the stage for what followed. ${ }^{4}$ Our more limited claim is that the organized plaintiffs' bar, as we know it today, "came of age" (Daniels and Martin 2003) in the second half of the 20th century. Indeed, a recent book celebrating the history of the Association of Trial Lawyers of America shows how the association grew from a small group of workers' compensation lawyers in the late 1940 s to the nation's largest specialty bar association by the end of the 20th century (Jacobson and White 2004). During the period covered by Corboy's career, the plaintiffs' bar grew from a small number of relatively marginal practitioners to a much larger, more prosperous, and more respectable group, and it is the nature of that transformation-the coming of age of a subprofession-that we wish to explore. ${ }^{5}$

\footnotetext{
4. There is conflicting opinion among American sociolegal scholars as to when and to what extent laws and juries became more favorable for plaintiffs. Friedman (2002) and Speiser (1980), for example, argue that the plaintiff-friendly climate is a product of 20th-century America. Prior to this, the fellow-servant rule prohibited a worker from suing his employer over the negligence of another employee. Under the privity doctrine, a consumer injured by a product could sue only the party that sold it to him (and not its manufacturer or producer). The "doctrine of charitable immunity" prohibited lawsuits against hospitals, churches, schools, or other charitable organizations. And under the "doctrine of contributory negligence" a plaintiff could not recover from a defendant if the plaintiff contributed (to any degree) to the accident himself. Accordingly, the chances for recovery were relatively slim, and even when plaintiffs prevailed, awards were nominal (Friedman 2002; Speiser 1980). However, Bergstrom (1992) investigated trends in civil cases in New York from 1870 to 1910, and found a "tort explosion" of personal injury suits at the turn of the century, despite the fact that negligence rules had not changed during the period. Bergstrom notes that while the number of personal injury suits rose, both plaintiff win rates and damages actually declined in New York between 1870 and 1910 . Karsten (1997, 1998), however, argues that the contingency fee had become an accepted practice in America by the mid-19th century and that injured plaintiffs fared well over the last half of the 19th century as American judges and juries held railroads and other corporate defendants to increasingly higher standards. Karsten (1997) concludes that when controlling for relative wages, personal injury awards in the late-19th century were even more generous than they were in the late-20th century. Resolving this debate is beyond the scope of this article.

5. Though we focus on Philip Corboy, there were a number of other elite members of the Illinois plaintiffs' bar who made significant contributions to the advancement of the profession and the liberalization of tort law during this period. Many, but not all, are mentioned in the telling of Corboy's story.
} 1998.

3. For a similar approach examining the law and society tradition, see Garth and Sterling 


\section{THE WORKING-CLASS ORIGINS AND SOCIAL NETWORKS OF THE PLAINTIFFS' BAR}

In the period after World War II, the legal profession appeared to a young lawyer like Corboy to be dominated by and for the corporate bar, which recruited almost exclusively from a WASP establishment legitimated with degrees from Ivy League schools (for confirming evidence see Heinz and Laumann 1982; Heinz, Nelson, et al. forthcoming). Corporate lawyers controlled the bar associations and played civic roles that reinforced their professional status. Catholics or Jews or the graduates of local law schools, doubly penalized for their working-class or immigrant backgrounds, had limited access to the corporate elite. ${ }^{6}$ Lacking this access, they typically followed a different track.

Born in 1924, Corboy was the eldest of three children. His parents, both children of Irish immigrants, attended Chicago Catholic schools and attained a high school education at most. His father and later his brother were Chicago police officers. His childhood was marked by adversity. His family defaulted and lost its home on Chicago's north side when Corboy was 14 years old. Despite those financial difficulties, Corboy attended Catholic grammar schools and a Catholic high school. With steady encouragement from an uncle who was a local priest, Corboy set his sights on college. He attended a series of different undergraduate institutions, but he never did graduate.

After serving in the army during World War II, Corboy took advantage of the opportunities under the GI Bill. He was able to enter Loyola University Law School, a local Jesuit law institution, because it waived the undergraduate degree requirement for students who had amassed enough college credit. Given the opportunity, he thrived. He graduated from Loyola as valedictorian in 1948.

Graduation at the top of his class, however, did not mean an abundance of professional opportunities. Corboy recalls the limited access to the corporate bar at the time:

They did not come on campus. They did not interview. I don't know how you got [a job with them], because I didn't get one. I think they acquired them from prestige law schools, mostly from the East. One, two schools in the Midwest, maybe Michigan and Chicago. Northwestern was still a regional school then.... I think they chose people who were from large law schools-I mean prestige law schools who were on the law review and all that. The same way they do today.

Corboy had one interview with a law firm, which at the time was a defense firm that represented the gas company. As he told it,

6. As Purcell observes, "Frequently a product of the allegedly inferior night law schools that began to spread in the 1890 s, the new urban personal injury attorney was often Catholic or Jewish and a product of the new immigration from southern and eastern Europe.... [T] that opened between the established bar and the personal injury bar grew as much from ethnic and social differences, real and perceived, as from their professional ones" $(1992,150)$. 
The Law School Dean sent me over there. [Despite my marks,] I did not get the job. The lawyer in my class who got the job was a fellow who did not-I won't tell you his name, it would not be fair to him, did not have the marks that the three of us who were sent over there had. He was in the middle of his class... somewhere. But he got the job. We found out later that his uncle was an executive of the gas company.

Corboy, however, was not without his own resources. As he stated,

I had an uncle, too. My uncle, at one time, he was a priest at St. John Bercham....[H]e sent me two places, my uncle did. He knew a lot of people. He sent me to the United States Attorney's Office, where I was interviewed and told to come back. Their telling me to come back, I was told later, guaranteed me a job as an Assistant United States Attorney.

Corboy figured that a Truman defeat would lead to losing his position in the U.S. Attorney's office, so he did not pursue it. To continue in his words,

So anyhow ... my uncle had gotten me a job in the [City of Chicago] Corporation Counsel's office. Again, he got me an interview. And that was all I needed, because I had very good marks. And I went to the Corporation Counsel's office.... And my job was librarian.... Got the library in shape. And at the same time, I took the bar exam.

At that time there were about 100 lawyers in the office of the Corporation Counsel. According to Corboy, about half of those people "stayed there for the rest of their lives," while the other "half ... became judges." Careers were built on a "seniority basis, plus political affiliation." Encouraged by his boss, Corboy became a precinct captain in the 49th ward in Chicago. He also ran for president of the Young Democrats of Cook County, losing in his first effort but succeeding the following year.

As suggested in Corboy's story, the careers then open to an Irish Catholic Loyola law graduate from the top of the class were those built through local Democratic politics and political contacts. In their book about Mayor Richard J. Daley and the Democratic machine, American Pharaoh, Cohen and Taylor note that "if the Irish did not run Chicago-most of the businesses, banks, and newspapers were in Protestant hands-they did dominate the Democratic machine out of all proportions to their numbers" $(2000,37)$. Cohen and Taylor and others have speculated that the Irish Catholic origins of the machine gave it a particular structure and flavor. Advancement required knowing one's place in the hierarchy, staying within an established role, maintaining strong social relations, and offering unconditional loyalty to the party.

Legal careers within the political machine provided an alternative track to the one available to the corporate bar. The predominantly Irish Catholic political system in Chicago produced politicians, U.S. attorneys, municipal 
corporation counsel, state's attorneys, and public defenders, and there were places in the judiciary to reward those who provided service in the other positions. The products of the system, as Corboy himself noted, were "shaped" and "matured" by the "pristine political system." He added, "When I started the practice of law, all judges came through the political system." The judiciary's background meant that they "understood people. That understanding of people made them very, very good judges." The Chicago plaintiffs' bar has its roots in this local political environment.

The close ties to local politics gave individuals such as Corboy access to a different set of resources and powerful actors from those of the corporate bar. This heritage did more than open doors for Corboy and others; it signaled similar life experiences and a shared worldview. Further, as we will see, many of the qualities of the Democratic machine (e.g., hierarchy, loyalty, strong social relations) are reproduced in the Chicago plaintiffs' bar. $^{8}$ Finally, as we shall also see, the close connection to Democratic politics has been crucial to the survival of the plaintiffs' bar when faced with business threats in the name of tort reform.

\section{THE EARLY PROFESSIONAL STRATEGY: FOCUS ON PROFESSIONAL RESPECTABILITY AND INDEPENDENT PROFESSIONAL ASSOCIATIONS}

Returning to Corboy's personal story, we can easily imagine a career in politics or the judiciary for this sharp young lawyer with good connections in Chicago Democratic politics. Corboy's uncle guided him into the office of the

7. The Chicago Lawyers studies confirm the proximity of Chicago plaintiffs' lawyers to the local bar leadership and the local Democratic political structure. In both 1975 and 1995, the Chicago Lawyers researchers asked respondents about their ties to a predetermined group of local elite lawyers or "notables." In both studies, the authors identified three broad clusters of notables, tied through their common connections. One cluster contained corporate notables; the second a group of liberal notables; and the third a set of trial lawyers that overlapped with bar leaders and political figures (Heinz and Laumann 1982; Heinz, Laumann, et al. 1997). Commenting on this finding in the 1975 data, Heinz and Laumann concluded: "The trial lawyers/CBA [Chicago Bar Association] sphere has clear political ties to the Regular Democrats. It is probable that one of the principal sources of the influence of this sphere is its ability to mobilize the resources of the city and county governments, to secure the benefits that it is within the power of City Hall to confer" $(1982,314)$.

8. There are indications that the purity of this system has been diluted in recent years. Corboy himself lamented the weakening of this system and Heinz et al. speculate that this may be attributable to the "decline in the fortunes of the Regular Democratic organization in Chicago and to the Republicans' control of the governor's office" that occurred after the death of Mayor Richard J. Daley in 1976 (Heinz, Nelson, et al. forthcoming). Nevertheless, there are still remnants today. Of the 53 Cook County Law Division judges who preside over personal injury and other civil disputes, two-thirds (68 percent-versus about 45 percent of the total bar in Chicago) attended a local Chicago law school (DePaul, Loyola, Kent, and John Marshall). These are the same four law schools that feed into the Chicago plaintiffs' bar (Parikh 2001). Further, most of today's Chicago plaintiffs' lawyers either began their career in personal injury (plaintiff or defense) or moved to the plaintiffs' bar from the state's attorney or public defenders office. 
Corporation Counsel and ensured that he would be given a good assignment there. As it turned out, however, Corboy's career took a notable detour less than two years after he began work at the Corporation Counsel's office. According to Corboy, "I was happy, I was content, I was secure, I was earning, I was doing things that lawyers many years my senior would never do. I was on a professional roll. Then out of the blue James Dooley entered my life."

James Dooley was another Irish Catholic graduate of Loyola, who unbeknownst to Corboy had even been a neighbor of his. Dooley was building a reputation in the emerging field of personal injury. At the time, according to Corboy, there were "two types of lawyers that handled personal injury cases. Those who acquire business and are either called litigation lawyers or they're just called personal injury lawyers; they don't try cases." Then there were those like Dooley, who "tried cases." Corboy had noticed that "Mr. Dooley, while I was in law school, he acquired the largest verdict up to that time. It was $\$ 185,000$."

Corboy had been marshal of the Phi Alpha Delta Law Fraternity, a position that Dooley had also held at Loyola. Corboy met Dooley when he invited Dooley to speak to the fraternity while Corboy was at Loyola. Dooley remembered the impression that Corboy made on him, and he later sought Corboy out to join Dooley's small personal injury practice. According to Corboy, Dooley and "probably five or six other lawyers" in Illinois represented a new breed of personal injury lawyer who excelled in jury trials. Dooley was the most prominent, and Corboy saw an opportunity to move into a practice that had begun to attract some attention at Loyola and more generally in the legal profession. Dooley's offer moved Corboy off the traditional local political track.

Dooley did not recruit from the corporate bar or the elite schools. Those with elite credentials still thought of personal injury lawyers as ambulance chasers with poor standards of professional ethics. Personal injury lawyers did not occupy prominent positions in professional organizations or have a reputation for trial craft. Dooley, Corboy could see, was working to distance himself and others like him who "tried cases" from the ambulance chasers and case processors. They had to gain legitimacy within a professional context that favored the corporate bar. Even the ethical rules were constructed to reinforce the status of corporate lawyers (Purcell 1992). As Carlin (1966) noted, handing out business cards at the country club was permitted, while handing out business cards in emergency rooms was not. Dooley was actively organizing to try to upgrade the reputation of a kind of practice-representing accident victims-long tarred by the professional elite.

Around this very time, in fact, many of the specialty associations devoted to plaintiffs' personal injury lawyers were first established. The predecessor to the Association of Trial Lawyers of America (ATLA) was founded in 1946 as the National Association of American Claimants' Attorneys (NAACA). Its early focus was on compensation for workers' injuries, but the famous tort lawyer Melvin Belli joined and contributed to its transformation 
into an organization for the plaintiffs' personal injury bar (Jacobson and White 2004, 74-75). The Illinois Trial Lawyers Association (ITLA) was founded in $1952 .{ }^{9}$ These organizations were devoted to raising the standards of the profession, to improving the reputation of the plaintiffs' bar, and to sharing information among members. Though not overtly political at their inception, both ITLA and ATLA had an early legislative agenda that sought to expand the legal rights of injured plaintiffs. One of the recurring debates in ATLA until the 1980 s was between those who wanted to put more emphasis on political activity versus those whose focus was more on education and professional reputation (Jacobson and White 2004, 201). ${ }^{10}$

Dooley was an early national leader of the plaintiffs' bar. Dooley was the first president of ITLA, serving from 1952 to 1955 , and he was one of the founders of NAACA. He was President of ATLA from 1953 to 1954, and president of the International Academy of Trial Lawyers in 1960. Through Dooley, Corboy saw the importance of investing in this collective selfimprovement effort.

According to a leading personal injury lawyer quite familiar with the careers of Corboy and Dooley, "There was one first generation and that was Jim Dooley. He was the most important progenitor of making personal injury practice respectable in Illinois. Prior to Jim Dooley, personal injury lawyers, I don't have to tell you, on the scale of hierarchy were, if not at the bottom, certainly close to the bottom. And Jim Dooley did more than anyone to change that. And Corboy trained under Jim Dooley." They sought to make the world of personal injury law respectable within the legal professional hierarchy.

The second part of the Dooley strategy was to gain respect for their craft as attorneys who tried cases. While a law practice focused on advice and negotiation had the highest prestige in the corporate bar at the time, the quest for professional respectability among personal injury lawyers militated in favor of investment in pure law-litigation-that would separate these lawyers from the taint of ambulance chasing and case processing. In 1959, Dooley secured the first million-dollar-plus jury verdict in Cook County in a work injury case involving 18 plaintiffs. Dooley's activities also included an extensive appellate practice seeking to expand tort law on behalf of plaintiffs. He reportedly appeared before the Illinois Appellate and Supreme Courts nearly 100 times during his career. ${ }^{11}$ In addition, Dooley invested in

9. Similar associations were established in other states around the same time. The Texas Trial Lawyers Association was founded in 1949, and the New York State Trial Lawyers Association was founded in 1953.

10. According to Jacobson and White, "Many viewed such special interest lobbying and political giving as distasteful and demeaning to the association. It was hugely expensive and threatened the educational programs that had brought ATLA growth and respect" (2004, 201). It appears that Dooley was on the side advising against aggressive political activity in the early days of ATLA (55).

11. According to Corboy, Dooley's "appellate advocacy was the genesis of many important opinions germane to the law of damages, negligence, due care and evidence" (Corboy 1979). 
scholarship, authoring a three-volume treatise, Modern Tort Law (1977). Dooley in these ways built his reputation for trial and doctrinal expertise and not incidentally helped promote liberalization in tort law. He continued to practice as a leading plaintiffs' lawyer until he was elected to the Illinois Supreme Court in $1976 .{ }^{12}$ His Supreme Court term was cut short by his sudden death in March 1978.

Under Dooley's tutelage, Corboy invested heavily in the practice of trying cases. He had his first jury trial within a month of starting with Dooley in 1950 . He won that case, though the judge later took away the verdict. During his two years with Dooley's firm, he conducted eight to ten jury trials, found his way around the Cook County Courthouse, and became acquainted with the repeat players on the plaintiff and defense sides. He watched when Dooley was on trial, and he met Dooley's professional colleagues through the newly established ITLA and through ATLA. He watched Dooley speak to these and other professional associations. In all these activities, Corboy learned the importance both of trial craft and of the organizations that would celebrate it. Corboy also learned from Dooley how to prosper without the overt taint of ambulance chasing. Dooley followed a professional strategy to get businessthrough referrals from other lawyers. With this experience under his belt, Corboy left Dooley's firm in 1952 to start his own practice. At the time, it was standard practice for a young personal injury attorney to learn the trade under an established player, then leave to build his own practice. An elite plaintiffs' lawyer explained:

It used to be that personal injury lawyers were lone wolves. They never had partners. It was usually a big-name lawyer with three or four associates. When they either made enough money, or got too antsy and knew they weren't going to be made partner, they'd go off on their own and start their own practice. Then [the mentor] would hire another associate and it would go on that way until he either died or retired.

Though it was common for younger lawyers to leave their mentors, this apprenticeship model had a strong element of paternalism. Dooley and Corboy maintained their relationship until Dooley's death. Dooley provided Corboy with early financial support, guidance, and advice on his cases, and encouraged his continued involvement in professional activities. When he went out on his own, Corboy borrowed $\$ 1,300$ from Dooley and another $\$ 2,500$ from a court reporter that he knew. Corboy eventually paid both of them back. Like Dooley, Corboy decided to specialize only in personal injury cases, though the value of those cases was much smaller than they would later become. Corboy also

12. Lacking the backing of the Daley machine, which favored another candidate, Dooley won in part by advertising extensively on television with the help of Chicago Bears football star Dick Butkus, whom he had helped in an injury suit against the Bears. 
deliberately set out to build a referral-based practice. Having seen how Dooley got business, when he went out on his own, he networked aggressively with other lawyers to generate business. Corboy recalls:

When I first got out of Mr. Dooley's office, I went to every lawyer who I met over in the courthouse and told them I was leaving and going out on my own. That is the first thing I did. I then took every opportunity there was to write or speak on the type of work that I thought I knew enough about. I did not go the route of going to Kiwanis, Better Business Bureau, Holy Name Society.... I didn't go that route at all. I did the professional route. I went only to professionals, only lawyers. I let them know that if they did refer a case, they would get a portion of the fee. $^{13}$

These activities paid off for his business and helped set the pattern of securing clients by referrals rather than through the less-professional routes followed by some other personal injury lawyers. Carlin (1962) found evidence of this referral system in the early 1960s. More recent studies reveal the central role that the referral system continues to play in the personal injury bar (Daniels and Martin 1999; Kritzer forthcoming; Kritzer and Krishnan 1999; Parikh 2001; Spurr 1988). The referral system ensures that the highervalue cases will, as a general rule, work their way up through the hierarchy of the plaintiffs' bar, thereby reinforcing the stratification in the profession and the dominance of the prevailing elite. As Parikh found in her examination of the lawyer referral system, personal injury lawyers work hard to develop and maintain these referral relationships, and having a referral-based business is a sign of prestige in the personal injury bar. Corboy reflected that "I think there is a feeling of accomplishment when another lawyer recognizes your specialty.... I like getting business from lawyers who think I'm competent." Another high-end plaintiffs' lawyer commented:

I don't mean to sound hoity-toity, because I know good attorneys who advertise. I think if you were to ask most plaintiffs' PI attorneys who have a desire to have a respected reputation in Chicago, given their druthers ... I think to a person, they'd say they'd rather not have to advertise. Having a good, strong referral base means that you don't have to do the other things that most attorneys desiring respect would want to avoid: advertising, chasing, having to work really hard to get cases.

When Corboy went out on his own, he got cases right away, 90 percent from other lawyers. He went from making $\$ 4,200$ a year with Dooley to $\$ 25,000$

13. The referring attorney often gets a fee just for sending the case, often a third of the attorney fee, or a ninth of the total award. 
a year on his own. ${ }^{14}$ Corboy also became active in professional associations dedicated to trial lawyers (ITLA, ATLA). He served as president of ITLA from 1963 to 1964.

\section{LIBERALIZING TORT LAW IN THE SOCIAL ACTIVIST 1960S}

The 1960s were watershed years for the plaintiffs' bar. They were able to improve their reputation with a combination of trial craft and professional bar activity, and they improved their economic position through legislative lobbying and legal arguments made to judges like themselves. The timing was right. They were in tune with the spirit of the socially activist state and indeed relatively moderate as a group in relation to the civil rights struggles and antiwar efforts. ${ }^{15}$

The Illinois courts and legislature broadened the playing field of possible defendants in product liability, medical malpractice, and construction injury disputes. ${ }^{16}$ Changes in discovery rules also made it easier for plaintiffs' attorneys to build their cases. ${ }^{17}$ Elite plaintiff and defense lawyers helped to define the rules that governed their growing field. ${ }^{18}$ Certainly there were differences in

14. Corboy's first "important case" came to him from a DePaul University Law School graduate who had been a member of the Phi Alpha Delta Fraternity at the same time as Corboy. The plaintiff was an army sergeant who was badly injured in an automobile accident. Corboy took the case to a jury in 1954 , and the jury awarded the plaintiff $\$ 50,000$, a very significant award at the time.

15. "ATLA as an organization was 'notoriously absent' from active participation" in the civil rights movement (Jacobson and White 2004, 168).

16. In 1965, ruling in Suvada v. White Motor Corporation (32 Ill. 2d 612, 210 N.E. 2d 182 [1965]), the Illinois Supreme Court introduced the concept of strict liability, which made a defendant liable, per se, if his product was defective, regardless of negligence or privity. This opened the doors for product liability disputes against manufacturers. That same year, in Darling v. Charleston Community Memorial Hospital (33 Ill. 2d 326, 211 N.E. 2d 253, 14 A.L.R. 3d 860 [Ill. Sep 29, 1965]), the Illinois Supreme Court ruled that hospitals are responsible for the actions of their staff, which expanded the market for and potential value of medical malpractice disputes. Also in 1965, the Illinois Restatement (Second) of Torts clarified the Structural Work Act, indicating that a contractor can be held liable for the actions of independent contractors under his control.

17. According to an elite personal injury lawyer commenting in retrospect on the changes, "Well, the climate changed... . [In the past] there were a lot of small cases, there was no discovery, depositions, and all the rest that we have. So, they basically got the file, did a little investigation, talked to their client, and went to trial. It was shoot from the hip, and then in the fifties and sixties, the discovery started, and when I started, almost nobody used expert witnesses. Expert witnesses were a rare breed; now you can't have a falldown case without an expert witness."

18. Responding to perceived problems with jury instructions, for example, the Illinois Supreme Court created the Illinois Pattem Jury Instruction Committee in 1957. The committee included both plaintiff and defense lawyers as well as members of the judiciary. Corboy was appointed to the committee on the recommendation of defense lawyers he had opposed in court. The committee's charge was to develop a set of standardized jury instructions. The Illinois Patterned Instructions (IPI), adopted in 1961, rationalized the instructions and not incidentally clarified the types of damages that could be awarded for personal injury. The committee decided 
perspective, but there was a shared sense that the law and practice of personal injury was developing in a positive fashion. The growing success in the courtroom fed further success in the appellate courts. As Corboy noted,

Before the Dooleys ... and other people came along, there were not many cases going up to the appellate court, because there were not many cases where the plaintiff won the case. Defendants were ... struck with larger verdicts starting in the ' 50 s, and the ' 60 s certainly. Then when a big verdict-an adequate verdict, not a big one, an adequate verdict, compensatory result came along at the trial level, they appealed them. And they acquired less and less success in the appellate court. The appellate and supreme courts responded to the needs of proper compensation.

One of the legislative keys to success in advancing the tort field in Illinois was the removal of the $\$ 30,000$ cap in wrongful death cases. According to Corboy, "I was very active from the very beginning in trying to take the limitation off. We went to every session of the [Illinois] legislature for-well, ten years would be five sessions. I think we probably started in the late "50s." Initially the legislature was not responsive: "The reaction was, until then it was keep it up. Keep the limit up. And the legislature was controlled-I shouldn't say controlled, that's too strong a word. The legislature was conservative. And they had the insurance companies backing them. And many of the legislators were Republicans." Finally in 1967, the Illinois Legislature eliminated the $\$ 30,000$ cap in wrongful death cases.

The combination of legislative and judicial changes would lead Nat Ozmon, ITLA president in 1969-70, to reminisce that "when we reached 1969 , the courtroom playing field for injury cases had been somewhat leveled" (ITLA 2002, 13). Corboy himself reflected on the period as follows:

We were waiting, without knowing it. We took advantage of that which was there. But then when the judiciary started taking advantage of our-acceptance of our arguments, that's when it really came in. And when lawyers became very successful in acquiring reasonable compensation for people and for particularly dead people who could no longer be required to be satisfied with $\$ 30,000$ when a horse's life was worth $\$ 90,000$, when judges understood that and legislators understood it, the tort revolution really got [going]. ${ }^{19}$

to model these new instructions after the Bay Area Jury Instructions (BAJI), which was reportedly the first set of instructions of its kind in the nation. Corboy chaired the subcommittee that drafted the jury instructions on damages. The new damages instructions guided the jury to compensate the plaintiff for disability, disfigurement, pain and suffering, medical expenses, lost wages, and "permanency." Only the permanency category would later be struck down by the courts. With this one exception, these instructions are still in use today.

19. One of the arguments that Corboy made to the legislature was that he had won $\$ 90,000$ in the case of wrongful death of a horse, but a man's life was worth only $\$ 30,000$. 
It is remarkable how little opposition there was to the reforms that permitted the expansion of the Illinois plaintiffs' bar in the 1960s. The Illinois Supreme Court participated in a national movement to bolster access to the courts and to provide adequate compensation for injured persons, and even the Republican-dominated legislature eventually saw the need to make legislative changes in harmony with what was happening in the courts. The openings in personal injury law were consistent with other legal programs such as the national movement to provide access to justice through legal aid reform, which began in the 1960s (see Johnson 1974). The tort revolution was not a matter of partisan politics, but rather of a social consensus consistent with the more activist state of the 1960s. In this climate, the larger political field was receptive to calls for better injury compensation by lawyers.

With the sociopolitical tide in their favor, none of the trial lawyer groups at that point had felt the need to engage in partisan political activity. According to Corboy, that activity did not begin until late in the 1960s. In Corboy's words, "there was no need.... there was no tort reform machine." The same was true at the national level. ATLA at that time did not have any particular political agenda (Burke 2002; Jacobson and White 2004). Until the late 1960 s, the elite of the personal injury bar could celebrate both increased respectability and a relatively unchallenged prosperity. The emerging elite within the personal injury bar focused mainly on issues of education and professional respectability.

The changes in the law started to translate into larger verdicts for injured parties. In April 1965, a Cook County jury awarded the first million-dollar verdict to a single plaintiff in Illinois. ${ }^{20}$ While the plaintiffs' bar crossed a significant threshold with this verdict, it was the only million-dollar verdict in Illinois in the 1960s. While Cook County juries had awarded only one milliondollar-plus verdict in the 1960 s, they awarded nearly 30 million-dollar-plus verdicts during the 1970s. We can see the concrete meaning of this prosperity through Corboy's personal story. In 1974, Corboy represented the estates of two men who were killed when the car they were riding in was rear-ended by an 18 wheel tractor-trailer. In September 1974, a Cook County jury awarded the plaintiff decedents a total of $\$ 1.7$ million. It was Corboy's first million-dollarplus verdict. Corboy secured his second million-dollar-plus verdict just three years later (1977), when a Cook County jury awarded $\$ 1.6$ million to a bricklayer who was injured from a fall when the scaffold he was standing on tipped over. Many other million-dollar verdicts were to follow.

20. The case arose from an airplane crash in which 37 passengers and eight crew members were killed when a Boeing 720 airplane, operated by Northwest Orient Airlines, crashed in the Florida Everglades while en route to Chicago. The plaintiff, Terese Hollerich, filed the suit on behalf of her husband, John, who died in the crash. Both Boeing and Northwest were found liable, and the jury awarded the plaintiff $\$ 2$ million. The plaintiffs' attorney was John Kennelly, another local Irish Catholic lawyer, who served as ITLA president from 1968 to 1969. 


\section{NO-FAULT LIABILITY, TORT REFORM, AND THE POLITICIZATION OF THE PLAINTIFFS' BAR}

The attack on the plaintiffs' bar did not begin with corporate America. As litigation picked up for a number of reasons, attention began to focus more on the personal injury sector. ${ }^{21}$ The major challenge began through the writings of two academics, Robert Keeton and Jeffrey O'Connell, who promoted no-fault automobile insurance as an efficient way to bring compensation to accident victims (see Burke 2002; Jacobson and White 2004, 185-201). Liberal Democrats led by Michael Dukakis in Massachusetts, along with a few insurance companies, also lined up behind no-fault. The relatively liberal impetus for this activity underscores the fact that plaintiffs' lawyers-despite their proximity in background to the Chicago Democratic Party-had operated by emphasizing professionalism, especially skill in litigation and bar service-and a consensus in favor of compensation for victims. Their political connections remained quite local as well, and they had not invested much in the legal academy. They now confronted a group of policy and academic professionals who sought to take them out of the picture at a time when personal injury lawyers depended largely on automobile accidents. Reflecting on this time, one local plaintiffs' lawyer said that "nofault would have ended the auto accident business and put all of the Irish and Jewish lawyers out of business."

In the late 1960s, no-fault legislation was introduced both at the national (Keeton-O'Connell Plan) and state level (Cotter Plan). Corboy and other leading Illinois plaintiffs' lawyers lobbied and advocated against these proposals. But the Illinois plaintiffs' bar was not yet set up to fight a battle of this scope. ITLA, for example, did not yet have its own lobbyist or even an executive director or office in the state capital. The plaintiffs' bar also found that its public image was not helpful to their fight: "The average uninsured driver liked what our opponents were saying.... [W]e had little media support and were seriously out-financed by our opponents who had wellestablished public relations networks" (ITLA 2002, 15-16).

Despite broad public support and well-financed backing from the insurance industry, no-fault did not succeed in Illinois in the 1960s. Yet, for the plaintiffs' bar, it was a harbinger of the fights ahead of them. They had begun to invest in politics, but politics at this time was far less intensive and expensive than it would become. The situation intensified beginning in the late

21. As early as 1963 , some members of the judiciary called for the elimination of jury trials in civil cases in order to reduce court backlog. In response, ITLA and other bar groups presented alternative remedies to reduce backlog. In the context of this debate, a local newspaper editorial argued that an idle judiciary was to blame for the court delays. After the editorial was published, Corboy quickly came out in defense of the judiciary, arguing on local television that Illinois judges "were not loafing," but were instead very busy handling significant caseloads and attempting to resolve disputes not only through jury trials, but also through settlement negotiations and dispositive motions. 
1960s when the no-fault movement began to morph into the more allencompassing tort reform movement. In 1969, ITLA held the "Trial and Tort Forum of 1969," and Nat Ozmon, the president, assessed the emerging challenge:

Today, as we hear from men who are experts in their fields and with that gift to be able to convey and teach to others, let us keep in mind that there is lurking within many circles, cloaked by various subterfuges, the individuals or groups who have as their intent to steal from our clients, our litigants, the fault principals of tort law. (ITLA 2002, 15) ${ }^{22}$

The opposition indeed took on steam in the 1970 s with a second no-fault movement and other tort reform measures. In the early 1970s, the Illinois Legislature passed the Compensation of Automobile Accident Victims statute, which, among other things, required the arbitration of automobile cases in smaller counties $(200,000$ or less) and in lower-value cases $(\$ 3,000$ or less) in larger counties. The statute also limited plaintiffs' recovery against owners of commercial vehicles, but not of private vehicles. With support from his peers, Leonard Ring, a leading Chicago plaintiffs' lawyer and past president of ITLA (1966-68), challenged the constitutionality of the statute in Grace $v$. Howlett, 51 Ill. 2d 478 (1972). The court overturned the statute, declaring it unconstitutional. Around the same time, the federal secretary of Transportation drafted a federal no-fault bill, and Democratic Senator Ted Kennedy got behind the bill and agreed to sponsor it. Tipped to the bill by Corboy's childhood classmate and friend, Congressman Henry Hyde (R-Ill), Illinois's elite plaintiffs' lawyers called upon friends in D.C. to stop the bill. The plaintiffs' bar succeeded in putting out this fire as well.

In addition to the no-fault automobile insurance movement, the medical community also mobilized against the tort system in the 1970s. In 1976, the Illinois legislature passed the Medical Malpractice Reform Act, which, among other things, imposed a $\$ 500,000$ cap on compensatory damages in medical malpractice disputes. Again, Leonard Ring and other leading Illinois plaintiffs' lawyers used a litigation strategy to challenge the new legislation in Wright v. Central DuPage Hospital Association (347 N.E. 2d 736 [Ill. 1976]). The Illinois Supreme Court again sided with the plaintiffs, invalidating the statute as unconstitutional.

The plaintiffs' bar fought tort reform both in the courts and through more direct political strategies. The key change taking place during this time

22. The hoofbeats of tort reform were heard not just in Illinois. Another speaker at the meeting, Richard Markus of Cleveland, and incoming president of ATLA, would echo Ozmon's words, in speaking of the "clouds on the horizon." Ozmon and Markus would be right. At the same time that they perfected their skills of persuasion in the courtroom and advanced into unforeseen markets, the plaintiffs' bar would spend the next three decades fighting off tort reform. 
was the increasing involvement of personal injury lawyers in Democratic politics. National Democratic politics had to a great extent fallen in line behind no-fault programs, and Illinois's legislature at one point had enacted no-fault as well.

Economic sociologists hold that in order to become stable, actors in an emerging market (or profession) must often gain access to and rely upon "powerful outside actors." ${ }^{23}$ Just as corporate lawyers cannot be understood apart from the businesses who are the basic source of their social and economic power, no amount of investment in professionalism could undo the reliance of the plaintiffs' bar on their ties to the Irish Catholic connections in the local Democratic Party. Corboy and other leading plaintiffs' lawyers in Chicago were in a perfect position to reshape their professional strategy and activate their affinity with and connections to the local Democratic Party. Corboy was himself well positioned to invest more in politics, as he suggested quite clearly in his discussion of his relationship with the late Mayor Richard J. Daley:

I was an admirer of Mr. Daley because he got things done. I was president of the Chicago Bar Association. Some issues came up concerning police involvement in the curtailment of crime. I asked to come over to the fifth floor [of City Hall] and discuss something concerning police cases. It had nothing to do with a specific case. And he invited me into his office and he confided in me. He talked with me like he had known me a long time. And I felt he trusted me. He knew I was of the same religion and same ethnic background as him.

In the face of no-fault and other emerging tort reform movements, accordingly, plaintiffs' lawyers made a concerted effort to establish ties to state legislators. ITLA, which had historically been devoted to networking, advancing the reputation of the profession, and knowledge sharing among trial lawyers, started to mobilize more forcefully as a political entity. In the early 1970s, ITLA opened an office in Springfield, the Illinois state capital, and hired its first executive director, whose primary duties were to "lobby legislators and restructure ITLA's operations" (ITLA 2002, 18). ${ }^{24}$ Also in the early 1970s, ITLA established the "HELP Trust" (Help Encourage Legislative Progress), which would later become the ITLA PAC (Political Action Committee).

23. Bourdieu expressed concern that the category of the "profession" actually conceals the ways that professions legitimate and obscure particular power arrangements in the state and the economy (Bourdieu and Wacquant 1992). Bourdieu recommended studies of the field within which a profession operates in order to make those obscure hierarchies more visible (1998, 35-60). Stated in more pragmatic U.S. terms, Fligstein argues that "social relations within and across firms and their more formal relations to the state are pivotal to understanding how stable markets emerge" $(2001,68)$. in 1977 .

24. Likewise, ATLA moved its national headquarters from Boston to Washington, D.C., 
The elite plaintiffs' lawyers in this way became major and sustained players in politics as a result of no-fault and its aftermath. ${ }^{25}$ They also became linked more directly to the Democratic Party. In the fight against no-fault, itself the product of academics and liberal politicians, some Republican defense lawyers also played important roles. John Bickley, ITLA's president from 1971 to 1972, a Republican and a lawyer with a defense firm, recalled that "several Republicans, including myself and several others from major defense law firms, were induced to take a most active role in the defeat of the [no-fault] legislation [in Illinois]" (ITLA 2002, 20). Yet this plaintiff-defense alliance was short-lived. ${ }^{26}$ The plaintiffs' bar ultimately invested not in a bipartisan professional strategy above politics but rather in the Democratic relationships that were already built into their careers and their personal histories. They sought to protect their clients and their practices increasingly through the Democratic Party at the local and national level. They shifted from a concentration on professional respectability to one that combined efforts to build professional status with intense political partisanship.

The activation of their links to Democratic Party in the 1970s and 1980s is also evident in the way that Corboy recalled the beginning of his relationship with Illinois House Speaker Michael Madigan during this time:

I met Michael Madigan about 20 years ago. I asked to meet him for the purpose of describing my views. I abruptly tell you because he has said this.... He did not know much about the antipathetic attitude of the Republican Party at the time.... And I educated him on the issues. And, ever since that time, I have been a fervent follower of Michael Madigan.

Madigan, like Corboy, graduated from Loyola law school. Madigan is still Speaker of the Illinois House and his daughter, Lisa Madigan, is the Illinois attorney general—elected with Corboy's support. ${ }^{27}$ The solidarity of the Democrats with the plaintiffs' bar has made it possible to defeat-either through legislation or judicial action-every major tort reform measure in Illinois.

Today, in fact, the very close ties to the Democratic Party are as much a part of the identity of the plaintiffs' bar as their commitment to professional

25. ITLA also instituted a sort of man-to-man defense strategy that John Mullen (ITLA president 1970-71) described as follows: "We had a lawyer working on and accountable for every Republican and Democrat legislator's vote. We had commitments from at least a majority of House and Senate and then we were present whenever there was a committee or floor vote to make sure the commitment was carried out" (ITLA 2002, 19).

26. Reminiscing on this collaborative period, Bickley lamented the loss of bipartisanship in ITLA: "Unfortunately ... we have regained the reputation that our organization is one of the more consistent props to the Democratic leadership in the legislature. As a consequence, Republican hopefuls are again reluctant to openly participate with us, as it subjects them to attacks within their local party entities" (ITLA 2002, 21).

27. Corboy's own daughter, Joan Corboy, was a Cook County judge before her accidental death in 1999. 
bar activity, trial craft, and the referral system that channels the largest cases to the elite of the subprofession. Corboy himself expresses unconditional devotion to the Democratic Party. "I'm a yellow dog Democrat. That's what people from Texas call themselves. They're Democrats because they believe the Democratic Party is the answer to government." Another high-end plaintiffs' lawyer talked about the practicalities of this allegiance:

I make contributions to whoever is the Democratic horse we're riding. That's unfortunate because I grew up believing that anybody who votes a straight ticket is not a thinking person. But, you know, for somebody who does what I do for a living, and the number one, two, and three item on the Republican agenda is tort reform ...

In Corboy's terms, "I contribute money and I raise money for whoever the candidate is. I consider it my responsibility. If I'm concerned about how government is run, I believe it's my responsibility to become involved in the government. That's my way of doing it." With this widespread practice, plaintiffs' lawyers are now among the nation's largest group of contributors to the Democratic Party. Indeed, between 1994 and 1999, Chicago's elite plaintiffs' lawyers contributed an average of $\$ 21,000$ each per year to statebased political campaigns and political action committees (Parikh 2001).

Plaintiffs' lawyers today do not have to reach out to establish contacts; they are sought after for their financial resources, for input on judicial candidates, and the like. In the words of Corboy, "Two senators called yesterday. One was from the State of Illinois. He was asking me my opinion of people who have been recommended for federal judgeships. There was another who wanted money from the State of Massachusetts." Another elite plaintiffs' lawyer noted, "I mean it's relentless. Relentless. And, you know, people think that plaintiffs' lawyers are just rolling in money. They call us every day. People running for Congress. People running for state rep. And nationally. Not just the president. You know, the attorney general in lowa. The plaintiffs' bar, we get hit a lot." Professional responsibility within this subprofession, in short, now includes an obligation to give generously to the Democratic Partywhich now embraces the plaintiffs' bar as well. To make the obvious point seen in national politics today, there are very strong personal and policy divisions now between the Republicans and the Democrats on the question of tort reform-an issue that energizes each side's stock of major contributors.

\section{INVESTING IN MAINSTREAM INSTITUTIONS}

While Dooley had limited his activities to the plaintiffs' bar, Corboy became active in general bar associations as well, particularly the Chicago Bar Association. Corboy and others could see that they needed to gain 
recognition in the general bar associations long dominated by the corporate bar. ${ }^{28}$ Corboy began to break down barriers in the legal profession in Illinois in the early 1970s. As we have noted, he was the first plaintiffs' attorney to be elected president of the Chicago Bar Association (1972-73). Corboy was also the first plaintiffs' lawyer to be named as chair of the ABA Section of Litigation (1979-80). These firsts were not only important for Corboy's career, but they also set the course for future generations of Chicago plaintiffs' lawyers. As Corboy noted, he "was the first plaintiffs' lawyer to get elected [to the Chicago Bar Association]. Since then, we've had five people in this office." Active professional involvement is part of the culture of the high-end plaintiffs' lawyer, and, in some firms, is even part of the job description. According to one elite plaintiffs' lawyer in a competing firm: "Corboy set the pattern for showing that you have a responsibility to the whole legal profession, not just the personal injury end of the profession. And that's something that I've taken very seriously.... Our firm has made it a requirement of every lawyer in this firm that we be active in various bar associations." Plaintiffs' lawyers had to work harder than their corporate counterparts to build their legitimacy. Corporate lawyers did not need the control of the bar associations to maintain their status and position. Plaintiffs' lawyers felt that they needed the credibility and the power of the bar associations in order to hold their own in the profession.

Corboy also followed the professional model of the corporate bar by building a philanthropic presence in the community. By the 1980 s Corboy was already well known as a local philanthropist, with scholarship and fellowship programs at high schools and colleges across the city. Most of these scholarship programs are designed to help individuals get access to education-consistent with Corboy's own background and commitment to young law clerks who have worked during school. Though his philanthropic focus is largely educational, his choice of where to contribute is highly personal and consistent with his position in the plaintiffs' bar. The recipients of his scholarships include Loyola University, his law school alma mater, DePaul University Law School, where his son went to school, and Northwestern University Law School, where his daughter attended. He also has a scholarship program at John Marshall Law School for police officers who want to attend law school. Corboy established this scholarship because his father was a policeman, and he chose Marshall because police officers can attend law school there while they continue to work. Finally, Corboy is a significant contributor to the Big Shoulders Fund, which provides money for underprivileged Chicago youth to

28. As Jacobson and White state, "Plaintiffs' lawyers had long had a prickly relationship with the American Bar Association. Nonetheless, ATLA's leaders in the 1960 s urged members to join the ABA and become active in their state bars" $(2004,195)$. The success of the relationship helped to defeat a resolution before the House of Delegates in 1969 supporting no-fault. 
go to private Catholic schools. ${ }^{29}$ An elite plaintiffs' lawyer from a competing firm talks about Corboy's legacy of philanthropy:

Corboy has been very generous with scholarships and with law school contributions.... And, you know, that certainly has had an influence on me.... I think that's a very good precedent. I know that the people that work with Corboy, he makes it known to them that that's something to be expected.... This profession has been very good to a lot of us. And you have to share that with other people. And I think Corboy has always felt that way too.

This strategy furthers the ambition of personal injury lawyers for higher professional status and helps to build relationships with the schools that feed into the personal injury bar and the social worlds in which they interact. The elite of the plaintiffs' bar continue to have a very strong interest in the well-being of a particular set of schools and institutions that provide external support for its own power.

\section{REPRODUCING THE PROFESSION}

Economic sociologists also note that markets (or professions) are internally hierarchical. Dominant actors seek to maintain their place in the hierarchy at the same time they work to advance the interests of the collective that sustains them. White (1981), for example, views markets as "self-reproducing social structures," and highlights the importance that relationships play in both perpetuating the market as a whole and in maintaining the internal hierarchy of the market. Fligstein notes that "[f]ields contain collective actors who try to produce a system of domination in that space. To do so requires the production of a local culture that defines social relationships between actors" $(2001,15)$. Similarly, the new institutionalism seeks to understand "how incumbents maintain their dominant positions." (Powell and DiMaggio 1991, 30).

We have seen how the characteristics that Corboy embodies became central to the plaintiffs' bar and its own internal hierarchy. Corboy and others of his generation succeeded in building the practice of personal injury law and generating larger verdicts and settlements. Threats to that success have come from the outside through various tort reform movements. There is also a potential danger from within the legal profession or the particular

29. Corboy recalled when Cardinal Joseph Bernardin of the Chicago Archdiocese approached him about contributing to the Big Shoulders Fund: "Cardinal Bernardin came into this office. This was in 1986, I believe... . He looked right at me. He had those clear blue northern Italian eyes. He said 'I'd like you to contribute $\$ 1$ million.' And I said, 'Well, how do you say no to a Cardinal?' He looked right at me and said, 'You don't.'" 
subprofession. Success may attract newcomers eager to share in the financial rewards generated by the more liberal environment but unwilling to respect the rules developed by the pioneers. Conceivably, for example, lawyers with elite credentials from high-prestige law schools might have tried an elite strategy for gaining a share of this market, or perhaps advertisers might have sought to change the hierarchy in favor of those who simply could find cases. On the face of it neither possibility seems very plausible, but that is because we assume that elite lawyers gravitate naturally to corporate law and that mass advertisers will be ostracized. In both cases, however, an expanding market might have provided places for a few not only to build lucrative practices but also to mount a professional challenge that might affect the hierarchy of credentials and approaches valued in the subprofession. As it turned out, however, the plaintiffs' bar in Illinois was able to grow and service the increased potential demand for their services without losing control or changing the rules that determine elite status.

By the 1970s, Corboy already began growing the next generation of plaintiffs' lawyers in Chicago. In his hiring practices and his mentoring philosophy, we can see just how Corboy reproduced a profession of lawyers much like himself and to the exclusion of others who do not fit the profile. In his words, "I like people who have to work in order to get their education. And, if they've worked then they know how to juggle, they know how to study, and they know how to get things done. That's how many of the people have worked out." The late Jim Demos, a Corboy protégé who left to start his own firm and served as ITLA's president in 1978-79, recalled Corboy's mentoring style: "He doesn't teach.... You absorb it through osmosisexcellence, hard work, and no shortcuts" (Elstrom 1989). When Corboy was asked how he spots a potentially successful young lawyer, he was quite explicit about finding and developing young lawyers in the Corboy model: "... the ones that act more like Corboy acts. The ones that have the same work ethic. The same ones who are just as inquisitive... those who are willing to give up much of their privacy and their personal life have a much better chance of success. Because that's the way l'd done it." Put another way, those with traditional elite credentials, often linked to advantaged family backgrounds, are welcome in large corporate firms, but not in the plaintiffs' bar. The plaintiffs' field seeks out those who prove themselves through hard work, come from a working-class background, and have a local law degree.

In the early 1970s, Corboy hired two young lawyers who perfectly fit the Corboy profile, and who would excel under the Corboy system of "mentoring by osmosis." In 1973, Corboy hired Thomas Demetrio, a recent graduate of the Illinois Institute of Technology's Kent College of Law. Demetrio grew up in Evanston, Illinois, and his father owned a local restaurant. Demetrio was introduced to Corboy through a Cook County judge that Demetrio clerked for while in law school. Under Corboy's tutelage, Demetrio quickly learned 
the ropes of a plaintiffs' practice, trying cases, networking with other lawyers, and getting involved in professional associations. Demetrio followed in Corboy's footsteps in numerous ways. Demetrio became a leader in professional associations, eventually becoming president of the Illinois Trial Lawyers Association (1988-89) and president of the Chicago Bar Association (1993-94). He wrote numerous articles related to the profession, appearing in trade publications, law reviews, and as editorials in local newspapers. ${ }^{30}$ Breaking with the long-standing tradition in which young plaintiffs' lawyers left their mentors to start their own practice, Corboy made Demetrio a partner in the early 1980s. Though the firm now has roughly 20 lawyers, the firm still operates under the name Corboy and Demetrio.

A year after Demetrio started with Corboy, Corboy hired Robert Clifford, a 1974 DePaul University Law School graduate. Like Demetrio, Clifford learned and benefited from Corboy's trial expertise, his social contacts, and his professional involvement. Unlike Demetrio, Clifford left Corboy in 1984 to start his own firm (Clifford Law Offices). In 1994, the two firms merged as Corboy, Demetrio and Clifford. The marriage was short-lived, however, lasting only a year. Clifford Law Offices reestablished its independence and today is one of the most successful plaintiffs' firms in Chicago, if not the nation. Every year since 1994, Chicago Lawyer magazine has published its "MillionDollar Settlement Survey," which details the top settlements ( $\$ 1$ million or more) in Illinois and the plaintiffs' firms who handled them. For example, the 2002 settlement survey reports 219 settlements totaling $\$ 723$ million (Chicago Lawyer 2002). Clifford Law Offices, also now with roughly 20 lawyers, topped the 2002 Million-Dollar Settlement Survey with 24 million-dollar-plus settlements totaling nearly $\$ 137$ million. Like Corboy and Demetrio, Clifford has been nominated to the Inner Circle of Advocates and has been named numerous times among the best attorneys in the nation. Clifford served as president of the Illinois Trial Lawyers Association (1990-91), and is only the second plaintiffs' lawyer (the first was Corboy) to serve as chair of the ABA Section of Litigation (2001-2).

Demetrio and Clifford were not the only successful plaintiffs' lawyers to get their start with Corboy. Dubbed by some as the "Philip Corboy University College of Law," Corboy's firm became the training ground for many of today's most successful Chicago plaintiffs' lawyers. A couple of quotations illustrate this phenomenon:

We, in fact consider ourselves to be a third generation Corboy spin-off. There are probably now close to 35 firms in the city that have a direct or indirect connection to the Corboy law firm.

30. Another example occurred in the late 1970 s when Demetrio was appointed to the Illinois Supreme Court Committee on Pattern Jury Instructions, the same committee that Corboy served on earlier in his career. 
What Phil Corboy has done over the years is that his firm has been a training ground.... Of course, Mr. Corboy does now have partners, and they have changed the whole structure. But, in the old days, you were expected to leave. People would leave and he would give them a bunch of cases. God bless him. He helped people.

As we see in Corboy's hiring and mentoring of Tom Demetrio, Bob Clifford, and others like him at the top of the plaintiffs' bar, the senior partners reproduce themselves in their hiring practices, often hiring working-class young men like themselves who attended a local law school. ${ }^{31}$ This preference for hiring lawyers "like themselves" and hiring them from local law schools creates barriers to entry for young lawyers who do not fit these characteristics.

The brand of professionalism embraced by the personal injury bar also highlights the modest personal characteristics (working-class background) of the successful plaintiffs' lawyer rather than the prestige of his or her degrees. Plaintiffs' lawyers draw upon their modest beginnings in their public rhetoric and in their appeal to juries. According to one young plaintiffs' lawyer, "So, the David and Goliath aspect of it .. . I've always been more of a pusher for the underdog." Corboy, writing about his term as president of ITLA, said, "Our peers worked long and hard and have their time, money and energy to affect the tort evolution and its compensatory age. Our clients-the brain damaged, the legless and unsighted-are now being properly compensated" (ITLA $2002,10) .{ }^{32}$ Stories of working-class men who now serve the underdog are ubiquitous in the rhetoric and self-concept of plaintiffs' lawyers. This rhetoric, along with their personal histories, distinguishes plaintiffs' lawyers from their corporate counterparts. It is part of their unique brand of professionalism.

We can see the success of this strategy of reproduction by osmosis through the trajectories of the protégés. During the late 1980s, Demetrio, Clifford, and other plaintiffs' lawyers of the new generation began to move up in professional associations, and to take on the political activities of their mentors. ${ }^{33}$ Demetrio served as president of ITLA from 1988 to 1989 , and

31. More than 90 percent of Chicago plaintiffs' lawyers are men (Parikh 2001).

32. This thetoric is also seen at the national level. Senator John Edwards, the 2004 Democratic candidate for vice president, embodies the plaintiff bar's model of professionalism. His father worked in textile mills and his mother was a postal employee. He was the first person in his family to graduate from college, and he positions himself as a champion for "ordinary people."

33. This new generation mobilized against its own tort reform challenge in the 1990 s. In 1995 , despite aggressive lobbying by the Illinois plaintiffs' bar, the Illinois State Legislature passed a broad tort reform bill. With the help of ITLA, a handful of elite Illinois plaintiffs' firms (including Corboy and Demetrio) got together and selected some of their own cases to challenge the constitutionality of the bill. These cases were filed together and eventually made their way to the Illinois Supreme Court. ITLA instituted its first special assessment, raising nearly $\$ 1$ million dollars from members to finance the case. With this funding, ITLA hired Laurence Tribe, a nationally renowned constitutional law professor from Harvard, to argue their case before the Illinois Supreme Court. In 1997, the Illinois Supreme Court ruled in the plaintiffs' favor and struck down the legislature's tort reform package as unconstitutional. 
Clifford served two years later, from 1990 to 1991 . Another elite plaintiffs' lawyer of Clifford and Demetrio's generation talked about this transition:

I didn't start moving up in the Illinois Trial Lawyers Association until probably the late 1980 s, when I started getting much more involved. But, that was the same time Tom Demetrio did and Joe Power did and Bob Clifford did, because Corboy [and other elites of Corboy's generation] were ready to turn that over to us at that time.

Another Corboy protégé who eventually left and established his own successful practice talked about Corboy's influence in his professional activities, and how these professional activities served not only a political purpose, but also a business and professional purpose.

When I joined him, Corboy was chair of the Section of Litigation of the ABA. Mr. Corboy was always active in bar work. It seemed like something you should do.... There are a number of reasons why it is important. It does help with business. I think it also helps you stay on top of what is going on in the legal community.

The elite of the plaintiffs' bar work together to pick appropriate people for particular professional offices. The above elite lawyer, who, at the time of the interview was running for office in a professional association, commented,

You can run for any office you want, but there are good people ahead of me who I have respect for. I'm not going to try and jump the line. I hope nobody tries to jump the line on me. I should be uncontested here in Chicago.... If you have shown some leadership, hopefully you will scare people off. They will say "Gee. He has been an officer for four or five years. He has done a good job." Then you won't get contested.

The professional culture of the plaintiffs' bar continues to include pressures to support the profession, both in terms of involvement in professional activities and in contributing to their political activities. This pressure is most acutely felt at the top of the plaintiffs' bar, where the relatively small group of elite lawyers watch each other. One elite member of the plaintiffs' bar talked about their tort reform battle of the mid-1990s: "The frustrating thing was the people who wouldn't give anything [to fight tort reform], who've made tremendous money in this practice. If I told you their names, you'd be shocked. It was sad. But most people came through." This gentle transition of power and the pressures to support the profession indicate the success of Corboy and those around him in building a subprofession that will survive succession. During the 1990s, in fact, Corboy handed over the day-today running of his firm to Tom Demetrio and to his son, Philip Corboy, Jr., a 
1978 DePaul Law School graduate who joined the firm in 1985 after starting his career at the Cook County State's Attorney's Office.

Perhaps most illustrative of how far the plaintiffs' bar has come in just 50 years is its prominence in the national scene. One example is how the plaintiffs' bar quickly mobilized in response to the terrorist attacks of September 11, 2001. Shortly after the attacks, Congress pondered granting immunity to the airlines in order to protect the industry. In the process, Congress sought counsel from the plaintiffs' bar, who argued on behalf of the September 11 Victim Compensation Fund in lieu of lawsuits against the airlines. ATLA leaders called for a moratorium on lawsuits resulting from the attacks, and most plaintiffs' lawyers demonstrated restraint. The ABA then created a Task Force on Terrorism and the Law that, among other things, reviewed and advised the government on the development and administration of the September 11 Victim Compensation Fund. Corboy protégé Robert Clifford, who was then chair of the ABA Section of Litigation, was asked to chair the terrorism task force. In addition, with support from ATLA, plaintiffs' lawyers established Trial Lawyers Care, a nonprofit program that provides free legal services to victims' families who are seeking compensation through the Victim Compensation Fund. Despite a rocky beginning, the fund was a success. The overwhelming majority of victims' families ( 95 percent) filed for compensation through the fund, waiving their right to sue the airlines (Chen 2003). The mobilization and cooperation of the plaintiffs' bar was critical to the voluntary moratorium on lawsuits and the success of the fund. The plaintiffs' bar is sufficiently cohesive to hold in check those who might be tempted to take advantage of the disaster to reap financial gain but jeopardize the hard-earned respectability of this subprofession. A more recent example of the rising prominence and influence of the plaintiffs' bar was the selection of John Edwards as the 2004 Democratic vice presidential candidate. His skills as a trial lawyer, his appeal to "ordinary Americans," and his fundraising network were all deemed assets to the Democratic ticket.

\section{CONCLUSION AND DISCUSSION}

\section{Markets and Status}

Consistent with the theoretical model of the "professionalism project," the strategies that Corboy and his counterparts pursued during this period undoubtedly served to build markets and status for the personal injury bar. Their professional status now is much higher than it was in the early 1950 s, reflected in part through the positions of power they have reached in such organizations as the American Bar Association. Robert Clifford's central role with the ABA in the post-September 11 period, for example, illustrates how the $A B A$ is willing to entrust vital professional issues to a leader of the 
plaintiffs' bar. From a market perspective, the plaintiffs' bar has succeeded in building and protecting a market that allows its most successful practitioners to prosper beyond their wildest dreams.

We also see how intertwined and mutually reinforcing these strategies are. The case referral system, for example, is most obviously a market strategy. It is a way to get business and control the market for the highest-stakes personal injury cases. At the same time, the referral system provides some distance from the market, thereby enhancing the professional status of those at the top. Similarly, political activities are certainly related to market protection and control, but they also enhance the status of the subprofession as leading plaintiffs' lawyers assume important roles in Democratic politics more generally.

\section{Social Context of the Field}

The field perspective-and this relational biography of Corboy-shows the import of the capital possessed by Corboy and others, including the capital that came from their connections to the Irish Catholic Democratic machine in Chicago. Corboy and his counterparts lacked the kind of traditional legal capital that provided access to the corporate bar and to economic power in Chicago. They also lacked the symbolic resources-elite degrees, professional bar leadership, and philanthropic service, for example-that provided legitimacy and credibility to the corporate bar. Yet their personal heritage gave plaintiffs' lawyers access to resources and relationships that they otherwise lacked as outsiders to the corporate bar, including their ties from birth to the Chicago Democratic machine. The plaintiffs' bar used the materials available to them to find strategies that would work in Chicago, and they constructed a subprofession, a supporting ideology, and a set of practices that made sense of what they had and what they were able to do.

They first built a distance from claims processors and sought professional solidarity with trial attorneys committed to trial craft. They also worked the courts and the legislature to advance their market interests. Consistent with the social consensus in the more activist 1960s, the courts and legislature liberalized many of the laws pertaining to personal injury. The consensus evaporated first with the challenge of no-fault brought by liberal academics and then from a strong corporate attack in the name of tort reform. Shifting emphasis somewhat, the plaintiffs' lawyers drew upon the social networks that were part of their heritage. Their working-class, ethnic, and religious backgrounds gave them access to the local political elite, and they drew on this political capital-the Chicago Democratic machine-as they struggled to protect their clients and themselves. As the tort reform movement took on steam, the plaintiffs' bar responded by developing a well-organized infrastructure for political mobilization. They also embraced the ideology of the underdog and the working class and rewarded those who followed in their footsteps. At the same time, they 
continued to seek broader professional recognition by following the patterns of the corporate bar, including investing in mainstream bar association leadership, and investing in legal education and in philanthropy more generally. ${ }^{34}$

David Wilkins's study of black Chicago lawyers reveals striking parallels between the development of the plaintiffs' bar in the second half of the 20 th century, and the evolution of the black bar in that same time period (forthcoming). For example, originally excluded from mainstream professional associations that were dominated by the white Protestant corporate elite, both plaintiffs' lawyers and black lawyers responded by establishing their own professional associations. ${ }^{35}$ Early on, both groups essentially operated in "parallel worlds" alongside mainstream professional associations that were dominated by the corporate elite. Eventually, both groups began to make headway into mainstream professional associations. Today, general bar associations are no longer the exclusive domains of the corporate elite. Instead, many formerly excluded groups-including plaintiffs' lawyers, black lawyers, and women lawyers-now play an active role in these associations and are represented in the leadership of these organizations.

In both groups, we also see a heavy reliance on social networks, within a relatively small subgroup, for career building and for advancing the interests of the collective. As the plaintiffs' bar relies heavily on referral networks for securing business, social networks among black Chicago lawyers are an important source of business and career advancement. Further, as we see in Corboy's story, the plaintiffs' bar made its way in part by drawing upon its longstanding social ties to the local Democratic machine. Likewise, Wilkins notes that the biggest transformation in Chicago politics between 1975 and 1995 was

34. A natural question is whether our study of Chicago is representative of the way that this subprofession operates generally. There are of course similarities between Chicago and other jurisdictions. Daniels and Martin (2003) find that the "coming of age" of the Texas plaintiffs' bar involved a similar attention to markets, politics, and professional ideology. Van Hoy (2003) also finds Indiana trial lawyers working to improve their position and professional reputation over the second half of the 20 th century. The variations are also quite notable, however. Indiana's legislature has proven to be more receptive to tort reform, and Van Hoy notes that many of the Indiana personal injury lawyers are Republicans (2003). The Texas story is very similar to Chicago's, but it appears that the group in Texas is considerably less homogeneous than in Chicago. In contrast to the central role that lawyer referral plays in an elite practice in Chicago, Kritzer notes that the leader of the plaintiffs' personal injury bar in Wisconsin is also the most aggressive advertiser in the state (Kritzer forthcoming). It is also interesting that plaintiffs' lawyers nationally have moved into new areas such as tobacco litigation (Mather 1998) and have drawn increasingly on class action suits. The Chicago plaintiffs' bar has not moved into these potentially lucrative markets. The plaintiffs' lawyers in different state settings who came together and sought to build status and professional success in the period after World War II had many things in common, but they also had to operate and build their subprofession in very different sociopolitical contexts. A close examination of structural histories akin to our Chicago story —and the links between the states may help to explain why plaintiffs' lawyers made different choices in building their markets and status in other states; why some elite personal injury lawyers have been able to stay on top; and why tort reform has been more successful in some states than in others.

35. The National Bar Association, an association composed primarily of black lawyers, was established in 1925 and the Cook County Bar Association, a local bar association of black lawyers, was established in 1914. 
a rise in black power, exemplified by the election of Mayor Harold Washington in 1983. Wilkins found that black lawyers in Chicago took advantage of their ties to this rising political power to further their individual careers and their collective advancement. While black power in Chicago declined after Washington's death in 1987, blacks still represent a significant power base in Chicago and black lawyers are intimately linked to this local black power base. Consistent with other studies that focus on emerging markets (or professions) within the context of a field, the history of the plaintiffs' bar, like the history of the black bar, is a story about the central role that social networks and local political power play in the making of a subprofession.

Of course, plaintiffs' lawyers and black lawyers are not the only groups with access to powerful outside actors. As suggested earlier, the corporate bar has advanced its position in part through its social connections to powerful corporate interests. As the defining characteristics of the personal injury bar and their ties to the local political elite emerged from their underprivileged social background, the defining characteristics of the elite corporate bar emerged from their relatively privileged social background and their ties to the economic power elite.

\section{Internal Hierarchy}

The story of Corboy's career also shows how the subprofession and the rules that define it came to reinforce a particular professional hierarchy. Corboy and his counterparts constructed a subprofession that promotes the leadership position of elite plaintiffs' lawyers, secures the best cases for that elite through an explicit and well-understood hierarchy and referral system, and ensures political protection for their markets and clients. The elite and the rank and file of the personal injury bar buy into the hierarchy and the characteristics that make it up-professional bar leadership, courtroom success, commitment to Democratic politics, and a distance from the ambulance chasing and undignified advertising of those who occupy lower positions in the subprofession's hierarchy. Elite status is reserved to those who pay their dues, come through the prevailing elite, and invest in the values and defer to the ideology of the subprofession. It is almost impossible to reach the elite of the Chicago plaintiffs' bar without following and reinforcing the model developed by Corboy and a few others, and indeed learning it through close enough contact to allow osmosis.

\section{Unique Professional Ideology}

The focus on the field also lends insight into the unique professional ideology of the plaintiffs' bar. Their working-class backgrounds not only provided them with a particular set of social relationships; they also became 
the basis for a distinctive professional ideology that reinforces their practice. We can see the ideology by comparing the story of the plaintiffs' bar with that of corporate law firms. The history of Skadden Arps, for example, shows the relative success of Skadden Arps in hiring increasingly from the most prestigious law schools (Caplan 1994). In doing so, they became more competitive in the labor market, and their associates with elite law school credentials served in building markets and status in the corporate bar. Chicago plaintiffs' lawyers, by contrast, recruit almost exclusively from local law schools. Similar recruiting is found in other locales (see, e.g., Kritzer forthcoming). Despite a powerful desire for status in the mainstream legal profession, these plaintiffs' lawyers have not sought to draw on the credentials and powerful professional networks that come from elite law schools. In fact, the plaintiffs' bar thrives in part because it has managed to resist some of the hierarchies embedded more generally in the profession. The plaintiffs' bar has made a virtue out of its own relative marginality. Rather than deny their working-class heritage and lack of connection to the elite law schools, they celebrate their differences. In doing so, they position themselves as uniquely qualified to serve their "disadvantaged" clients, creating both a market niche and a professional niche that at once defines and protects their place in the system. The alignment with the Democratic Party (the party of "ordinary people") reinforces their identity as underdogs fighting on behalf of those who cannot help themselves.

The personal injury bar is not the only subsector of the legal profession that mirrors the social background of its clients. Traditional criminal defense lawyers, for example, also, like their clients, come from more modest backgrounds. Yet, as Kenneth Mann has shown, defense lawyers that specialize in white-collar crime tend to work for elite corporate firms and come from higherstatus groups-again consistent with the social background of their clients (1985). ${ }^{36}$ As Heinz and Laumann (1982) have observed, the American legal profession is an "over-determined social system." The stratification in the legal profession originates in, and is deeply rooted in, the larger society.

While the unique professional ideology of the plaintiffs' bar solidifies and protects their market niche, the focus of Chicago plaintiffs' lawyers on local law schools, working-class backgrounds, and local philanthropy perpetuates the relatively lower status of the plaintiffs' bar and reinforces the dominant position of the corporate bar. Since the legal profession in the United States tends to place corporate lawyers at the top of the hierarchy, they do not as a rule have to work as hard for professional credibility as the lawyers in the plaintiffs' bar. Of course, some corporate lawyers invest in bar activities, philanthropy, scholarship, pro bono work, and other legitimating activities. But the ethic of the plaintiffs' bar-at least in Chicago-requires virtually all members of the elite to engage in all these activities. And yet, despite

36. We thank an anonymous reviewer for raising this important observation. 
increasing numbers of bar presidents and ever more impressive philanthropy, the plaintiffs' bar cannot come close to matching the prestige of the corporate bar-which, after all, defined the rules. Since the status hierarchies continue to be tilted strongly toward the corporate bar, the plaintiffs' bar will remain somewhat suspect no matter how professionally pure their behavior is or how impure is that of their corporate counterparts. Indeed, while the plaintiffs' bar ranks fourth of 42 legal fields in mean income, it ranks only 32 nd of 42 fields in terms of professional prestige (Heinz, Nelson, et al. forthcoming). Further, the tort reform movement continues to gain ground in many settings, and the plaintiffs' bar must continually defend its activities and its profession. To some extent, then, we could say that the "professionalism project" of the plaintiffs' bar has succeeded only by degrees. While the plaintiffs' bar has developed an established subprofession and stable market niche, its legitimacy within the legal profession and even society at large remains suspect.

Just as the particular characteristics of this subprofession are not inevitable, the continued strength of the plaintiffs' bar is not guaranteed. ${ }^{37}$ One way to challenge this dominance would be to seek to change the rules to give value to different forms of capital - the ability to serve more people quickly rather than excel in litigation, for example, or the ability to challenge practices of major corporations through class actions and complex negotiated settlements. There is some evidence of these kinds of challenges, but they have not yet made headway in Chicago. There could also be external challenges that change the value of the capital in the field. Suppose, for example, that the corporate bar expanded so rapidly that it was able to dry up the source of talent for the plaintiffs' bar in local law schools, leading to a change in the profile of the local law schools as they reorient themselves to a new constituency. Or the Democratic Party could decide that the plaintiffs' bar is a liability, perhaps in response to some controversy or if tort reform became so successful that it reduced the ability of plaintiffs' lawyers to support the party. Such events could change the dynamics of the field and even the rules for what and who is valued. These are speculations, of course, but the general point is that an analysis based on the field can illustrate both the staying power and the fragility of a particular hierarchy built with a particular marketsupported by an attendant ideology and brand of professionalism.

Nevertheless, this analysis shows that the plaintiffs' bar in Chicago is especially remarkable for its ability to construct and preserve a unique professional identity, limit entry into the profession, and channel investment into the institutions that serve the subprofession and its hierarchy. Corboy's long-standing tenure as "dean" of the Chicago personal injury bar is a cause

37. A reviewer noted that the personal injury bar shares many characteristics with medieval guilds (including local orientation, selective admissions, apprenticeship, strong associations with outside power, a commitment to their craft, and a referral-based business) (see Krause 1996). Like today's personal injury bar, the guilds once enjoyed monopoly power over their local markets. Their heyday, of course, has passed. 
and result of that success. While consistent with the work on the ways that professions may protect markets and status, attention more generally to the sociopolitical context of the field shows how the "selection" of strategies depended on the resources and capital that certain actors, including Corboy, could mobilize, invest, and institutionalize at a certain historical juncture, and it shows how and why their success led to embedding the personal injury bar in a complex world of working-class ideology, trial craft, professional bar leadership, Democratic politics, local philanthropy, and a market referral system that favors the established elite of the plaintiffs' bar.

\section{REFERENCES}

Abel, Richard L. 1989. American Lawyers. New York: Oxford University Press. . 2003. English Lawyers between Market and State. New York: Oxford University Press.

Abel, Richard L., and Philip S. C. Lewis. 1995. Lawyers in Society: An Overview. Berkeley and Los Angeles: University of California Press.

Bergstrom, Randolph E. 1992. Courting Danger: Injury and Law in New York City, 18701910. Ithaca, N.Y.: Cornell University Press.

Bourdieu, Pierre. 1998. Practical Reason. Stanford, Calif.: Stanford University Press.

Bourdieu, Pierre, and Loic J. D. Wacquant. 1992. An Invitation to Reflexive Sociology. Chicago: University of Chicago Press.

Burke, Thomas F. 2002. Lawyers, Lawsuits, and Legal Rights: The Battle over Litigation in American Society. Berkeley and Los Angeles: University of California Press.

Caplan, Lincoln. 1994. Skadden: Power, Money, and the Rise of a Legal Empire. New York: Noonday Press.

Carlin, Jerome. 1962. Lawyers on Their Oun: A Study of Individual Practitioners in Chicago. New Brunswick, N.J:: Rutgers University Press.

- 1966. Lawyer's Ethics: A Survey of the New York City Bar. New York: Russell Sage Foundation.

Chen, David W. 2003. Applicants Rush to Meet Deadline for Sept. 11 Fund. New York Times, December 23.

Chicago Lawyer. 2002. 2002 Million-Dollar Settlement Survey, Chicago Lawyer (October).

Cohen, Adam, and Elizabeth Taylor. 2000. American Pharaoh: Mayor Richard J. Daley, His Battle for Chicago and the Nation. Boston: Little, Brown.

Corboy, Philip H. 1979. Justice James A. Dooley Loyola University Law Journal, Winter, $10(2)$.

Daniels, Stephen, and Joanne Martin. 1999. "It's Darwinism-Survival of the Fittest": How Markets and Reputations Shape the Ways in which Plaintiffs' Lawyers Obtain Clients. Law and Policy 21: 377-99.

- 2000. The Dynamic Nature of the Plaintiffs' Bar: Entrepreneurs and Innovation. Presented at the annual meeting of the Law and Society Association Meetings, Miami, Fla.

- 2003. Coming of Age in Texas: Markets, Politics, and Self-Identity in the Development of the Plaintiffs' Bar. Presented at the annual meeting of the Law and Society Association, Pittsburgh, Penn.

Dezalay, Yves, and Bryant G. Garth. 2002. The Internationalization of Palace Wars: Lawyers, Economists, and the Contest to Transform Latin American States. Chicago: University of Chicago Press. 
Dooley, James A. 1977. Modern Tort Law: Liability and Litigation. Chicago: Callaghan and Company.

Elstrom, Peter J. 1989. Courting Disaster: Flamboyant Corboy Wins Trials, Praise, Big Income, Crain's Chicago Business 12 (July 31-August 6): 31.

Fligstein, Neil. 2001. The Architecture of Markets: An Economic Sociology of Twenty-firstCentury Capitalistic Societies. Princeton, N.J.: Princeton University Press.

Friedman, Lawrence M. 2002. American Law in the 20th Century. New Haven, Conn: Yale University Press.

Garth, Bryant G., and Joyce Sterling. 1998. From Legal Realism to Law and Society: Reshaping Law for the Last Stages of the Social Activist State. Law and Society Review, 32: 409-71.

Heinz, John P. and Edward O. Laumann. 1982. Chicago Lawyers: The Social Structure of the Bar. New York: Russell Sage Foundation; Chicago: American Bar Foundation.

Heinz, John P., Edward O. Laumann, Robert L. Nelson, and Paul S. Schnorr. 1997. The Constituencies of Elite Urban Lawyers. Law and Society Review 31: 441-72.

Heinz, John P., Robert L. Nelson, Rebecca Sandefur, and Edward O. Laumann. Forthcoming. Urban Lawyers: The New Social Structure of the Bar. Chicago: University of Chicago Press.

ITLA. 2002. Illinois Trial Lawyers Association's 50th Anniversary Celebration: Honoring Our Past. Celebrating Our Future (September).

Jacobson, Richard S., and Jeffrey R. White. 2004. David v Goliath: ATLA an the Fight for Everyday Justice. Washington, D.C.: Association of Trial Lawyers of America.

Johnson, Earl, Jr. 1974. Justice and Reform: The Formative Years of the Oeo Legal Services Program. New York: Russell Sage Foundation.

Karsten, Peter. 1997. Heart versus Head: Judge-Made Law in 19th-Century America. Chapel Hill: University of North Carolina Press.

- 1998. Enabling the Poor to Have Their Day in Court: The Sanctioning of Contingency Fee Contracts; A History to 1940." DePaul Law Review 47: 231-60.

Krause, Eliott A. 1996. Death of the Guilds: Professions, States, and the Advance of Capitalism, 1930 to Present. New Haven, Conn: Yale University Press.

Kritzer, Herbert M. 1997. Contingency Fee Lawyers as Gatekeepers in the Civil Justice System. Judicature 81: 22-29.

- 2001. "From Litigators of Ordinary Cases to Litigators of Extraordinary Cases: Stratification in the Plaintiffs' Bar in the 21st Century. DePaul Law Review 51: 219 40.

- (forthcoming). Risks, Reputations and Rewards: Contingency Fee Legal Practice in the United States. Stanford, Calif: Stanford University Press.

Kritzer, Herbert M., and Jayanth K. Krishnan. 1999. Lawyers Seeking Clients, Clients Seeking Lawyers: Sources of Contingency Fee Cases and the Implications for Case Handling. Law and Policy 21: 347-75.

Larson, Magali Sarfatti. 1977. The Rise of Professionalism: A Sociological Analysis. Berkeley and Los Angeles: University of California Press.

Mann, Kenneth. 1985. Defending White Collar Crime: A Portrait of Attomeys at Work. New Haven, Conn: Yale University Press.

Mather, Lynn. 1998. Theorizing about Trial Courts: Lawyers, Policymaking, and Tobacco Litigation. Law and Social lnquiry 23: 897-940.

Parikh, Sara. 2001. Professionalism and Its Discontents: A Study of Social Networks in the Plaintiffs' Personal Injury Bar. Doctoral dissertation, Department of Sociology, University of Illinois at Chicago.

Powell, Walter W., and Paul J. DiMaggio. 1991. The New Institutionalism in Organizational Analysis. Chicago: University of Chicago Press. 


\section{LAW \& SOCIAL INQUIRY}

Purcell, Edward A. 1992. Litigation and Inequality: Federal Diversity Jurisdiction in Industrial America, 1870-1958. New York: Oxford University Press.

Speiser, Stuart M. 1980. Lawsuit. New York: Horizon Press.

Spurr, Stephen J. 1988. Referral Practices among Lawyers: A Theoretical and Empirical Analysis. Law and Social Inquiry (Winter): 85-109.

Swedberg, Richard. 2003. Principles of Economic Sociology. Princeton, N.J.: Princeton University Press.

Van Hoy, Jerry. 1999. Markets and Contingency: How Client Markets Influence the Work of Plaintiffs' Personal Injury Lawyers. International Journal of the Legal Profession 6: 345-66.

. 2003 Professional Projects and Professional Reputations: The Indiana Trial Lawyers' Association and Status within the Plaintiffs' Personal Injury Bar. Presented at the annual meeting of the Law and Society Association. Pittsburgh, Penn.

White, Harrison. 1981. Where Do Markets Come From? American Journal of Sociology 87: $517-47$.

Wilkins, David. Forthcoming. The Black Bar: The Legacy of "Broun v. Board of Education" and the Future of Race and the American Legal Profession. New York: Oxford University Press. 